\title{
Combined effect of land preparation methods and planting geometry on the performance of machine transplanted rice (Oryza sativa $L_{\text {.) }}$
}

\author{
R. B. Negalur ${ }^{1}$, A. S. Halepyati ${ }^{2}$, and B. G. Masthanaredy ${ }^{3}$ \\ Agricultural Research Station, Gangavathi, University of Agricultural Sciences, Raichur-583227 (Karnataka), INDIA \\ *Corresponding author. E-mail: tushberkipilli@rediffmail.com
}

Received: January 28, 2016; Revised received: July 29, 2016; Accepted: October 21, 2016

\begin{abstract}
Field experiment on effect of land preparation methods and planting geometry on growth and yield of machine transplanted rice (Oryza sativa L.) was conducted at Agricultural Research Station, Gangavathi, University of Agricultural Sciences, Raichur, Karnataka during kharif, 2012 and 2013 in clay soil under irrigated condition. Pooled mean indicated that, among the different land preparation methods and planting geometry puddling with rotovator fb levelling with spike tooth harrow and planting geometry of $30 \times 21 \mathrm{~cm}$ recorded significantly higher growth parameters viz., Leaf area index ( 2.87 and 1.56, respectively), dry matter accumulation in leaves (13.44 and 14.43 g plant $^{-1}$, respectively), dry matter accumulation in stem (26.25 and 29.31 g plant $^{-1}$, respectively), dry matter accumulation in panicles ( 37.21 and $41.38 \mathrm{~g} \mathrm{plant}^{-1}$, respectively), total dry matter accumulation in plant (73.82 and $85.12 \mathrm{~g} \mathrm{plant}^{-1}$, respectively), thousand grain weight (18.17 and 18.71,g respectively), grain yield (4906 and $5192 \mathrm{~kg}$ $\mathrm{ha}^{-1}$, respectively), straw yield (6247 and $6508 \mathrm{~kg} \mathrm{ha}^{-1}$, respectively), gross returns (Rs. 87,733 and $92779 \mathrm{ha}^{-1}$, respectively), net returns (Rs. 46329 and $50007 \mathrm{ha}^{-1}$ ) and benefit cost ratio (2.14 and 2.20). Puddling with rotovator fb levelling with spike tooth harrow and $30 \times 21 \mathrm{~cm}$ spacing were found better for transplanting of rice by self propelled mechanical transplanter. Land preparation would be helpful as one of the important pre requirement in machine transplanting of rice, which in turn will decide the time (time required for settling of soil particle) and type of machine to be used for transplanting of rice.
\end{abstract}

Keywords: Dry matter accumulation, Economics, Land preparation methods, Machine transplanting, Manual planting, Planting geometry

\section{INTRODUCTION}

Rice (Oryza sativa L.) is considered as the "global grain". It is the major staple food for more than half of the global population. Asian countries consume about 90 per cent of the rice grown and produced in the world and supplies 50 to 80 per cent calories of energy to Asians. Rice is the anchors of food security in the world with challenges of climate change which is grown under wide range of latitudes and altitudes (Anonymous, 2008).

Texturally fine and moderately fine soils such as clayey and clay loam having clay as dominant component are ideal for rice cultivation. These soils have high water holding capacity, less water intake rate and can support power unit and implements while being operated for puddling in standing water. For rice, the basic qualification of the prepared soil is that it should be as compact and impermeable below the rooting depth as possible in order to impede the downward movement of water to the maximum. However, the root zone soil must be well pulverised and cultured for proper nourishment of plants (Razzaq, 1987).

Mechanical cultivation can easily achieve the objectives provided farmers are shown the benefits of using appropriate implements. At the moment farmers owning tractors normally hold and use conventional cultivator for preparing rice fields. The cultivator is the only soil opening tool. It has less pulverizing action and least sealing effect at any level. As a result, many repeats of cultivator followed by planking are required to transform the soil into condition where rice nursery can be transplanted. The only combination of cultivator and plank tend to compact the surface of soil instead of transforming impermeability below the root zone. Such practice entails poor land manipulation at the cost of energy, time and machinery life and low yield of rice. The study of inter-relationship of soil, implement and crop is very much required (Behera et al., 2009).

There are various tillage methods used to prepare land for rice cultivation. The effect of these tillage methods on hydraulic conductivity, infiltration rate, bulk density, cone index and rice yield are quite different. The use of suitable tillage practices/implements in each region depends on different factors such as water availability, topography, climate, soil texture, type of rice culture, percolation, depth of water table, soil compaction, aggregation etc. (De Datta et al., 1988). 
Spacing is very important for optimum plant population per unit area and will be reflected on the yield of the crop. A dense population of crops may have limitations in the maximum availability of resource factors. It is, therefore, necessary to determine the optimum density of plant population per unit area for obtaining maximum yield. Optimum plant spacing ensures plants to grow properly both in their aerial and underground parts through different utilization of solar radiation and nutrients (Duraisamy et al., 2011).

Mechanical transplanting not only facilitates better stand establishment of the rice crop at right time but also allows the genotype to exhibit phenotypic characteristics completely. Therefore, it is high time for mechanizing the transplanting operation in rice cultivation. Mechanical transplanting needs a suitable rice seedlings transplanter. Mechanical transplanter using self-propelled transplanter has been considered as the most promising option because it saves labour to the tune of 90 per cent of that required in manual transplanting, minimizes stress and drudgery, ensures timely transplanting and attains optimum plant density contributing to higher productivity (Behera, 2000). The present study was conducted to investigate the combined effect of land preparation methods and planting geometry on the performance of machine transplanted rice (Oryza sativa L.).

\section{MATERIALS AND METHODS}

A field experiment was conducted at Agricultural Research Station, Gangavathi, University of Agricultural Sciences, Raichur, Karnataka, during kharif, 2012 and 2013. The experiment was laid in strip-plot design. The soil of the experimental site was medium deep black clay with soil reaction (8.2), electrical conductivity (2.1) determined following the procedure given by Jackson (1973), available $\mathrm{N}\left(247.2 \mathrm{~kg} \mathrm{ha}^{-1}\right)$ Subbaiah and Asija (1956), available $\mathrm{P}_{2} \mathrm{O}_{5}(50.2 \mathrm{~kg}$ ha $\left.{ }^{1}\right)$ Olsen et al. (1954) and available $\mathrm{K}_{2} \mathrm{O}(357.6 \mathrm{~kg}$ ha $\left.{ }^{1}\right)$ Jackson (1973) at surface 0-20 cm soil depth.

Agricultural Research Station, Gangavathi is situated in the Northen Dry Zone of Karnataka between $15^{\circ} 15^{\prime}$ $40^{\prime \prime}$ North latitude and $76^{\circ} 31^{\prime} 40^{\prime \prime}$ East longitude at an altitude of $419 \mathrm{~m}$ above mean sea level and represents irrigated transplanted rice belt of Tungabhadra command area. The experiment consisted three different land preparation methods viz., $\mathrm{L}_{1}$ : passing of cultivator twice fb puddling with disc puddler fb levelling with spike tooth harrow - Farmers practice, $\mathrm{L}_{2}$ : puddling with rotovator fb levelling with spike tooth harrow and $\mathrm{L}_{3}$ : puddling with rotomixure fb levelling with spike tooth harrow and three planting geometry planted by transplanter viz., $\mathrm{S}_{1}: 30 \times 7 \mathrm{~cm}, \mathrm{~S}_{2}: 30 \times 14 \mathrm{~cm}$ and $\mathrm{S}_{3}: 30 \times 21 \mathrm{~cm}$ along with manual transplanting with $20 \times 10 \mathrm{~cm}$ spacing $\left(\mathrm{S}_{4}\right)$. The land was prepared using tractor drawn cultivator twice, followed by puddling twice with disc puddler and finally levelled using tractor drawn spike tooth harrow in case of farmers practice. Second type of land preparation was puddling with rotovator followed by levelling using tractor drawn spike tooth harrow. The other one was puddling with rotomixure and levelling was done using spike tooth harrow and kept ready for planting and seedlings raised in the trays were planted in the main field. Six days after transplanting, butachlor $50 \mathrm{EC}$ at the rate of 2.5 liter $\mathrm{ha}^{-1}$ was sand mixed and broadcasted uniformly over the field containing a thin film of water followed by two hand weedings at 20 and 40 days after transplanting. From the day of transplanting upto 10 days, a thin film of water was maintained and thereafter $5 \mathrm{~cm}$ standing water was maintained upto 10 days before harvesting. Water was drained during fertilizer application and spraying of chemicals. Recommended dose of fertilizers (150:75:75 and $20 \mathrm{~kg} \mathrm{~N}: \mathrm{P}_{2} \mathrm{O}_{5}: \mathrm{K}_{2} \mathrm{O}$ and $\mathrm{ZnSO}_{4} /$ ha) were applied as per the recommendation and time. Urea, Di-ammonium phosphate (DAP) and Muriate of potash (MOP) were used to supply N, P and $\mathrm{K}$ respectively. Before application, the land was drained and fertilizers were uniformly broadcasted over the field followed by letting in of water 24 hours after application. The recommended package of practices was fallowed. The crop was harvested at physiological maturity, threshed and cleaned manually in both the years. Both grain and straw were sun dried for a week and dry weights were recorded. For computing the cost of cultivation, different variable cost of items was considered. The cost includes expenditure on seeds, fertilizers, irrigation, plant protection chemicals, hiring charges of transplanter, fuel cost and labour charges prevailed in market during 2012 and 2013.

\section{RESULTS AND DISCUSSION}

\section{Growth parameters}

Land preparation methods: Significant response to both methods of land preparation and planting geometry was exhibited by rice. Pooled data of two years indicated that significantly higher Leaf area index (2.87), dry matter accumulation in leaves (13.44 g plant $\left.^{-1}\right)$, dry matter accumulation in stem $(0.44 \mathrm{~g}$ plant $\left.^{-1}\right)$, dry matter accumulation in panicles $(37.21 \mathrm{~g}$ plant $\left.^{-1}\right)$, total dry matter accumulation in plant $(73.82$ $\mathrm{g} \mathrm{plant}^{-1}$ ) (Tables 1 and 2) were recorded with puddling with rotovator fb levelling with spike tooth harrow method of land preparation over passing of cultivator twice $\mathrm{fb}$ puddling with disc puddler fb levelling with spike tooth harrow, but was found to be on par with puddling by rotomixure fb levelling with spike tooth harrow. The higher dry matter production in case of puddling with rotovator fb levelling with spike tooth harrow method of land preparation perhaps may be attributed to enhanced growth parameters like plant height at harvest, number of leaves at 60 DAT and higher leaf area at all the growth stages of crop as a 
Table 1. Leaf area index, DMA in leaves and DMA in stem of machine transplanted rice at different growth stages as influenced by land preparation methods and planting geometry (Pooled data of two years).

\begin{tabular}{|c|c|c|c|c|c|c|c|c|c|}
\hline \multirow{2}{*}{ Treatments } & \multicolumn{3}{|c|}{ Leaf area index } & \multicolumn{3}{|c|}{$\begin{array}{c}\text { DMA in leaves } \\
\left(\mathrm{g} \text { plant } \mathrm{t}^{-1}\right)\end{array}$} & \multicolumn{3}{|c|}{ DMA in stem } \\
\hline & 30 DAT & 60 DAT & $\begin{array}{c}\text { At har- } \\
\text { vest }\end{array}$ & 30 DAT & 60 DAT & $\begin{array}{c}\text { At har- } \\
\text { vest }\end{array}$ & $\begin{array}{c}\text { 30 } \\
\text { DAT }\end{array}$ & 60 DAT & $\begin{array}{c}\text { At har- } \\
\text { vest }\end{array}$ \\
\hline \multicolumn{10}{|c|}{ Main treatments $(\mathrm{L})$} \\
\hline$\overline{\mathrm{L}_{1}}$ & 1.82 & 3.44 & 2.55 & 3.13 & 13.42 & 12.26 & 4.06 & 20.28 & 23.44 \\
\hline $\mathrm{L}_{2}$ & 1.98 & 3.76 & 2.87 & 3.51 & 14.60 & 13.44 & 4.36 & 22.46 & 26.25 \\
\hline $\mathrm{L}_{3}$ & 1.94 & 3.66 & 2.82 & 3.34 & 14.30 & 13.15 & 4.22 & 21.12 & 25.25 \\
\hline S.Em. \pm & 0.03 & 0.05 & 0.06 & 0.07 & 0.23 & 0.19 & 0.23 & 0.36 & 0.41 \\
\hline C.D. $(\mathrm{P}=0.05)$ & 0.10 & 0.18 & 0.20 & NS & 0.90 & 0.73 & NS & 1.40 & 1.61 \\
\hline \multicolumn{10}{|c|}{ Sub treatments (S) } \\
\hline$\overline{S_{1}}$ & 2.67 & 5.12 & 3.88 & 3.19 & 13.90 & 12.67 & 4.01 & 19.62 & 23.37 \\
\hline $\mathrm{S}_{2}$ & 1.42 & 2.72 & 2.15 & 3.59 & 14.53 & 14.05 & 4.42 & 22.25 & 26.44 \\
\hline $\mathrm{S}_{3}$ & 1.01 & 1.95 & 1.56 & 3.97 & 15.89 & 14.43 & 4.62 & 25.45 & 29.31 \\
\hline $\mathrm{S}_{4}$ & 2.53 & 4.70 & 3.39 & 2.57 & 12.10 & 10.64 & 3.78 & 17.84 & 20.79 \\
\hline S.Em. \pm & 0.10 & 0.11 & 0.11 & 0.14 & 0.36 & 0.36 & 0.18 & 0.94 & 0.81 \\
\hline C.D. $(\mathrm{P}=0.05)$ & 0.34 & 0.37 & 0.37 & 0.48 & 1.25 & 1.24 & NS & 3.25 & 2.79 \\
\hline \multicolumn{10}{|c|}{ Interaction (L x S) } \\
\hline $\mathrm{L}_{1} \mathrm{~S}_{1}$ & 2.62 & 4.96 & 3.67 & 3.02 & 13.37 & 12.42 & 3.92 & 18.65 & 21.15 \\
\hline $\mathrm{L}_{1} \mathrm{~S}_{2}$ & 2.73 & 5.23 & 3.89 & 3.30 & 14.25 & 12.89 & 4.12 & 20.83 & 24.91 \\
\hline $\mathrm{L}_{1} \mathrm{~S}_{3}$ & 2.67 & 5.17 & 4.06 & 3.23 & 14.09 & 12.72 & 4.00 & 19.38 & 24.04 \\
\hline $\mathrm{L}_{1} \mathrm{~S}_{4}$ & 1.40 & 2.66 & 2.10 & 3.44 & 14.27 & 13.87 & 4.13 & 21.11 & 25.34 \\
\hline $\mathrm{L}_{2} \mathrm{~S}_{1}$ & 1.45 & 2.77 & 2.20 & 3.72 & 14.67 & 14.18 & 4.67 & 23.31 & 27.78 \\
\hline $\mathrm{L}_{2} \mathrm{~S}_{2}$ & 1.42 & 2.72 & 2.14 & 3.60 & 14.64 & 14.09 & 4.47 & 22.31 & 26.21 \\
\hline $\mathrm{L}_{2} \mathrm{~S}_{3}$ & 0.98 & 1.88 & 1.51 & 3.73 & 15.34 & 14.02 & 4.52 & 24.36 & 27.91 \\
\hline $\mathrm{L}_{2} \mathrm{~S}_{4}$ & 1.03 & 2.03 & 1.61 & 4.24 & 16.37 & 14.80 & 4.68 & 26.65 & 30.64 \\
\hline $\mathrm{L}_{3} \mathrm{~S}_{1}$ & 1.01 & 1.95 & 1.56 & 3.93 & 15.97 & 14.47 & 4.67 & 25.35 & 29.38 \\
\hline $\mathrm{L}_{3} \mathrm{~S}_{2}$ & 2.28 & 4.27 & 2.89 & 2.34 & 10.69 & 8.74 & 3.65 & 17.00 & 19.34 \\
\hline $\mathrm{L}_{3} \mathrm{~S}_{3}$ & 2.68 & 5.01 & 3.76 & 2.78 & 13.12 & 11.87 & 3.95 & 19.06 & 21.64 \\
\hline $\mathrm{L}_{3} \mathrm{~S}_{4}$ & 2.64 & 4.82 & 3.52 & 2.59 & 12.50 & 11.33 & 3.74 & 17.46 & 21.38 \\
\hline S.Em. \pm & 0.10 & 0.11 & 0.07 & 0.17 & 0.60 & 0.18 & 0.31 & 1.04 & 0.23 \\
\hline C.D. $(\mathrm{P}=0.05)$ & NS & NS & 0.21 & NS & NS & 0.57 & NS & NS & 0.70 \\
\hline
\end{tabular}

NS - Non significant; $\mathrm{L}_{1}$ : Cultivator (twice) fb pudling with disc puddler fb spike tooth harrow (PF); $\mathrm{L}_{2}$ : Puddling with rotovator fb spike tooth harrow; $\mathrm{L}_{3}$ : Puddling with rotomixture fb spike tooth harrow; $\mathrm{S}_{1}: 30 \times 7 \mathrm{~cm} ; \mathrm{S}_{2}: 30 \times 14 \mathrm{~cm} ; \mathrm{S}_{3}: 30 \times 21 \mathrm{~cm} ; \mathrm{S}_{4}: 20 \times 10 \mathrm{~cm}$

result of better utilization of nutrients as compared to other methods of land preparation. These findings are in conformity with the studies of Razzaq (1987) who reported that the highest yield was due to better tillering which was observed under this combina-tion of implements and Rahamati and Solakhe (2001) highlighted the production of higher number of panicles, tillers and yield (4.27 $\left.\mathrm{t} \mathrm{ha}^{-1}\right)$.

Planting geometry: Rice growth parameters were significantly influenced by different planting geometry. Planting geometry of $30 \times 21 \mathrm{~cm}$ recorded significantly higher dry matter accumulation in leaves (14.43 g plant $\left.{ }^{-1}\right)$, dry matter accumulation in stem (29.31 $\mathbf{g}$ plant $\left.{ }^{-}\right)$, dry matter accumulation in panicles $(41.38 \mathrm{~g}$ plant $\left.^{-1}\right)$, total dry matter accumulation in plant $(85.12 \mathrm{~g}$ plant $^{-1}$ ) and thousand grain weight (18.71) over manual planting at spacing of $20 \times 10 \mathrm{~cm}$, however, it was followed by intra plant spacing of $30 \times 14 \mathrm{~cm}$ (Tables 1 and 2). The increased dry matter production in case of $30 \times 21 \mathrm{~cm}$ spacing might be due to obvious reasons of optimum plant population, better leaf area and availability of nutrients, water and energy so also wider feeding area offered by planting in wider row spacing resulting in opportunity for greater root growth, increased availability and accessibility of nutrients to rice plants as reported by Duraisamy et al. (2011) observed significantly higher dry matter production by a wider spacing of $30 \times 22 \mathrm{~cm}$ over $30 \times 32 \mathrm{~cm}$ and $30 \times$ $16 \mathrm{~cm}$ due to obvious reasons of optimum plant population. Sannagoudra et al. (2012) attributed increased dry matter accumulation to plants grown with wider spacing having more area of land to draw the nutrients from and compensate for the low nutrient level of the soil. The plants also were exposed more to solar radiation which encouraged superior photosynthetic process.

\section{Yield}

Land preparation methods: Methods of land preparation had significant influence on yield parameters of rice. Significantly higher grain yield $\left(4906 \mathrm{~kg} \mathrm{ha}^{-1}\right)$ and straw yield $\left(6247 \mathrm{~kg} \mathrm{ha}^{-1}\right)$ were recorded with puddling by rotovator fb levelling with spike tooth harrow method of land preparation over passing of cultivator twice fb puddling with disc puddler fb levelling with spike tooth harrow (Table 3). However it was found to be on par with puddling by rotomixure $\mathrm{fb}$ levelling with spike tooth 
Table 2. DMA in panicles, Total dry matter accumulation and Thousand grain weight ofrice at different growth stages as influenced by land preparation methods and planting geometry.

\begin{tabular}{|c|c|c|c|c|c|c|c|c|c|}
\hline \multirow[b]{2}{*}{ Treatments } & \multicolumn{3}{|c|}{ DMA in panicles (g plant $\left.{ }^{-1}\right)$} & \multicolumn{3}{|c|}{ Total DMA (g plant $\left.{ }^{-1}\right)$} & \multicolumn{3}{|c|}{ Thousand grain weight (g) } \\
\hline & 2012 & 2013 & Pooled & $\begin{array}{c}\text { 30 } \\
\text { DAT }\end{array}$ & 60 DAT & $\begin{array}{c}\text { At har- } \\
\text { vest }\end{array}$ & 2012 & 2013 & Pooled \\
\hline \multicolumn{10}{|c|}{ Main treatments $(\mathrm{L})$} \\
\hline $\mathrm{L}_{1}$ & 32.56 & 35.26 & 33.91 & 7.18 & 33.75 & 69.39 & 17.31 & 16.96 & 17.14 \\
\hline $\mathrm{L}_{2}$ & 35.98 & 38.43 & 37.21 & 7.87 & 37.21 & 76.75 & 18.12 & 18.21 & 18.17 \\
\hline $\mathrm{L}_{3}$ & 34.64 & 36.89 & 35.77 & 7.56 & 35.49 & 73.82 & 17.58 & 17.52 & 17.55 \\
\hline S.Em. \pm & 0.59 & 0.47 & 0.56 & 0.38 & 0.44 & 0.89 & 0.26 & 0.35 & 0.29 \\
\hline C.D. $(\mathrm{P}=0.05)$ & 2.3 & 1.84 & 2.22 & NS & 1.72 & 3.50 & NS & NS & NS \\
\hline \multicolumn{10}{|c|}{ Sub treatments $(\mathrm{S})$} \\
\hline $\mathrm{S}_{1}$ & 32.38 & 34.77 & 33.57 & 7.19 & 33.52 & 69.50 & 17.17 & 17.07 & 17.12 \\
\hline $\mathrm{S}_{2}$ & 35.86 & 38.52 & 37.19 & 8.01 & 37.15 & 76.86 & 18.03 & 18.03 & 18.03 \\
\hline $\mathrm{S}_{3}$ & 40.1 & 42.66 & 41.38 & 8.59 & 41.34 & 85.12 & 18.67 & 18.74 & 18.71 \\
\hline $\mathrm{S}_{4}$ & 29.23 & 31.50 & 30.37 & 6.34 & 29.94 & 61.80 & 16.80 & 16.41 & 16.61 \\
\hline S.Em. \pm & 0.96 & 1.06 & 0.93 & 0.48 & 1.17 & 2.17 & 0.29 & 0.33 & 0.30 \\
\hline C.D. $(\mathrm{P}=0.05)$ & 3.34 & 3.67 & 3.21 & NS & 4.06 & 7.50 & 0.99 & 1.13 & 1.04 \\
\hline \multicolumn{10}{|c|}{ Interaction $(\mathrm{L} \times \mathrm{S})$} \\
\hline $\mathrm{L}_{1} \mathrm{~S}_{1}$ & 30.93 & 33.20 & 32.07 & 6.93 & 32.01 & 65.63 & 16.75 & 16.27 & 16.51 \\
\hline $\mathrm{L}_{1} \mathrm{~S}_{2}$ & 33.60 & 35.67 & 34.63 & 7.42 & 35.08 & 72.43 & 16.40 & 15.72 & 16.06 \\
\hline $\mathrm{L}_{1} \mathrm{~S}_{3}$ & 32.60 & 35.43 & 34.02 & 7.23 & 33.46 & 70.44 & 17.50 & 17.33 & 17.42 \\
\hline $\mathrm{L}_{1} \mathrm{~S}_{4}$ & 34.07 & 37.67 & 35.87 & 7.57 & 35.61 & 74.23 & 17.20 & 16.97 & 17.08 \\
\hline $\mathrm{L}_{2} \mathrm{~S}_{1}$ & 37.45 & 39.40 & 38.43 & 8.38 & 38.58 & 79.85 & 17.80 & 17.80 & 17.80 \\
\hline $\mathrm{L}_{2} \mathrm{~S}_{2}$ & 36.07 & 38.50 & 37.28 & 8.07 & 37.25 & 76.43 & 18.05 & 18.10 & 18.08 \\
\hline $\mathrm{L}_{2} \mathrm{~S}_{3}$ & 37.53 & 40.50 & 39.02 & 8.25 & 39.69 & 80.94 & 16.61 & 15.94 & 16.28 \\
\hline $\mathrm{L}_{2} \mathrm{~S}_{4}$ & 42.37 & 45.03 & 43.70 & 8.92 & 43.01 & 89.14 & 18.50 & 18.35 & 18.43 \\
\hline $\mathrm{L}_{3} \mathrm{~S}_{1}$ & 40.40 & 42.43 & 41.42 & 8.60 & 41.31 & 85.26 & 15.40 & 15.03 & 15.22 \\
\hline $\mathrm{L}_{3} \mathrm{~S}_{2}$ & 27.70 & 29.66 & 28.68 & 5.98 & 27.68 & 56.76 & 17.03 & 16.67 & 16.85 \\
\hline $\mathrm{L}_{3} \mathrm{~S}_{3}$ & 30.50 & 33.63 & 32.07 & 6.73 & 32.18 & 65.58 & 18.61 & 18.85 & 18.73 \\
\hline $\mathrm{L}_{3} \mathrm{~S}_{4}$ & 29.50 & 31.20 & 30.35 & 6.32 & 29.96 & 63.06 & 18.83 & 18.90 & 18.87 \\
\hline S.Em. \pm & 0.97 & 0.88 & 0.74 & 0.94 & 1.19 & 0.54 & 0.50 & 0.93 & 0.47 \\
\hline C.D. $(\mathrm{P}=0.05)$ & NS & NS & NS & NS & NS & 1.66 & NS & NS & $\mathrm{NS}$ \\
\hline
\end{tabular}

NS - Non significant; $\mathrm{L}_{1}$ : Cultivator (twice) fb pudling with disc puddler fb spike tooth harrow $(\mathrm{PF}) ; \mathrm{L}_{2}$ : Puddling with rotovator $\mathrm{fb}$ spike tooth harrow; $\mathrm{L}_{3}$ : Puddling with rotomixture fb spike tooth harrow; $\mathrm{S}_{1}: 30 \times 7 \mathrm{~cm} ; \quad \mathrm{S}_{2}: 30 \times 14 \mathrm{~cm} ; \mathrm{S}_{3}: 30 \times 21 \mathrm{~cm} ; \mathrm{S}_{4}$ : $20 \times 10 \mathrm{~cm}$

harrow method of land preparation. The higher yield of rice in case of puddling with rotovator $\mathrm{fb}$ levelling with spike tooth harrow was mainly due to the fact that puddling with rotovator reduced bulk density and cone index in the plough layer compared to other land preparation methods. Similar findings were reported by Rahamati and Solakhe (2001) reported increased rice yield due to reduction in cone index and bulk density in plough layer (0-15) and also decreased hydraulic conductivity and infiltration rate over this depth and Tripathi et al. (2004) observed that the yield of crop grown by transplanter was more even though the plant population was less than the manually transplanted one. This is to due to the higher number of effective tillers in the former crop than in the later. The crop planted through transplanter produced higher plant height, more number of effective tillers $\mathrm{m}^{-2}$ and more number of grains per panicle which contributed to higher yield when compared with manual planting

Planting geometry: Significantly higher grain yield $\left(5192 \mathrm{~kg} \mathrm{ha}^{-1}\right)$ and straw $\left(6508 \mathrm{~kg} \mathrm{ha}^{-1}\right)$ were noticed with planting at a spacing of $30 \times 21 \mathrm{~cm}$ as compared to manual planting at a distance of $20 \times 10 \mathrm{~cm}$. How- ever, it was found on par with planting geometry of 30 $\mathrm{x} 14 \mathrm{~cm}$ with respect to number of panicles $\mathrm{m}^{-2}$, panicle length and straw yield, while it was followed by with respect to number of filled grains per panicle, filling percent and grain yield. These results are in agreement with the findings of (Duraisamy et al (2011) who reported higher grain yield in wider spacing and the same was attributed to the enhanced stature of yield attributes, forming larger sink size coupled with efficient translocation of photosynthates to the sink, when the crop was raised under optimum planting pattern. Naidu et al. (2013) reported wider spacing leads to enhanced root growth, more productive tillers and ultimately leads to higher grain yield. Rasool et al. (2013) reported increased rice grain yield due to wider spacing, as the wider spacing adopted appears to be an advantageous factor for better development of panicles resulting in higher panicle length, panicle weight, spikelets number and filled grains panicle ${ }^{-1}$.

Grain and straw yield of machine transplanted rice was influenced significantly due to interaction of land preparation methods and spacing between the plants. Puddling with rotovator $\mathrm{fb}$ levelling with spike tooth 
Table 3. Grain yield, straw yield and harvest index of machine transplanted rice as influenced by land preparation methods and planting geometry.

\begin{tabular}{|c|c|c|c|c|c|c|c|c|c|}
\hline \multirow{2}{*}{ Treatments } & \multicolumn{3}{|c|}{ Grain yield $\left(\mathrm{kg} \mathrm{ha}^{-1}\right)$} & \multicolumn{3}{|c|}{ Straw yield $\left(\mathrm{kg} \mathrm{ha}^{-1}\right)$} & \multicolumn{3}{|c|}{ Harvest index } \\
\hline & 2012 & 2013 & Pooled & 2012 & 2013 & Pooled & 2012 & 2013 & Pooled \\
\hline \multicolumn{10}{|c|}{ Main treatments (L) } \\
\hline $\mathrm{L}_{1}$ & 4474 & 4576 & 4525 & 5609 & 5688 & 5648 & 0.45 & 0.45 & 0.45 \\
\hline $\mathrm{L}_{2}$ & 4859 & 4953 & 4906 & 6199 & 6295 & 6247 & 0.44 & 0.44 & 0.44 \\
\hline $\mathrm{L}_{3}$ & 4749 & 4851 & 4800 & 5830 & 5909 & 5870 & 0.45 & 0.45 & 0.45 \\
\hline S.Em. \pm & 49 & 47 & 50 & 109 & 83 & 104 & 0.00 & 0.00 & 0.00 \\
\hline C.D. $(\mathrm{P}=0.05)$ & 192 & 183 & 196 & 430 & 326 & 409 & NS & NS & NS \\
\hline \multicolumn{10}{|l|}{ Sub treatments (S) } \\
\hline $\mathrm{S}_{1}$ & 4538 & 4640 & 4589 & 5704 & 5789 & 5747 & 0.44 & 0.45 & 0.45 \\
\hline $\mathrm{S}_{2}$ & 4810 & 4911 & 4861 & 6109 & 6194 & 6152 & 0.44 & 0.44 & 0.44 \\
\hline $\mathrm{S}_{3}$ & 5147 & 5237 & 5192 & 6465 & 6550 & 6508 & 0.44 & 0.45 & 0.45 \\
\hline $\mathrm{S}_{4}$ & 4283 & 4385 & 4334 & 5238 & 5323 & 5280 & 0.45 & 0.45 & 0.45 \\
\hline S.Em. \pm & 71 & 60 & 78 & 128 & 124 & 132 & 0.01 & 0.01 & 0.01 \\
\hline C.D. $(\mathrm{P}=0.05)$ & 245 & 207 & 269 & 444 & 430 & 457 & NS & NS & NS \\
\hline \multicolumn{10}{|l|}{ Interaction (L x S) } \\
\hline $\mathrm{L}_{1} \mathrm{~S}_{1}$ & 4278 & 4379 & 4329 & 5698 & 5778 & 5738 & 0.43 & 0.43 & 0.43 \\
\hline $\mathrm{L}_{1} \mathrm{~S}_{2}$ & 4715 & 4817 & 4766 & 5823 & 5919 & 5871 & 0.45 & 0.45 & 0.45 \\
\hline $\mathrm{L}_{1} \mathrm{~S}_{3}$ & 4621 & 4723 & 4672 & 5592 & 5671 & 5632 & 0.45 & 0.46 & 0.46 \\
\hline $\mathrm{L}_{1} \mathrm{~S}_{4}$ & 4741 & 4843 & 4792 & 6000 & 6079 & 6040 & 0.44 & 0.45 & 0.45 \\
\hline $\mathrm{L}_{2} \mathrm{~S}_{1}$ & 4872 & 4974 & 4923 & 6278 & 6374 & 6326 & 0.44 & 0.44 & 0.44 \\
\hline $\mathrm{L}_{2} \mathrm{~S}_{2}$ & 4816 & 4917 & 4867 & 6049 & 6129 & 6089 & 0.44 & 0.45 & 0.45 \\
\hline $\mathrm{L}_{2} \mathrm{~S}_{3}$ & 5354 & 5422 & 5388 & 6741 & 6837 & 6789 & 0.45 & 0.45 & 0.45 \\
\hline $\mathrm{L}_{2} \mathrm{~S}_{4}$ & 5067 & 5168 & 5118 & 6401 & 6481 & 6441 & 0.44 & 0.44 & 0.44 \\
\hline $\mathrm{L}_{3} \mathrm{~S}_{1}$ & 5020 & 5122 & 5071 & 6253 & 6333 & 6293 & 0.45 & 0.45 & 0.45 \\
\hline $\mathrm{L}_{3} \mathrm{~S}_{2}$ & 3811 & 3913 & 3862 & 4335 & 4414 & 4375 & 0.47 & 0.47 & 0.47 \\
\hline $\mathrm{L}_{3} \mathrm{~S}_{3}$ & 4497 & 4598 & 4548 & 5953 & 6049 & 6001 & 0.43 & 0.43 & 0.43 \\
\hline $\mathrm{L}_{3} \mathrm{~S}_{4}$ & 4541 & 4643 & 4592 & 5425 & 5504 & 5465 & 0.46 & 0.46 & 0.46 \\
\hline S.Em. \pm & 102 & 99 & 103 & 216 & 207 & 217 & 0.01 & 0.01 & 0.01 \\
\hline C.D. $(\mathrm{P}=0.05)$ & 314 & 305 & 318 & 667 & 637 & 668 & NS & NS & NS \\
\hline
\end{tabular}

NS - Non significant; $\mathrm{L}_{1}$ : Cultivator (twice) fb pudling with disc puddler fb spike tooth harrow (PF); $\mathrm{L}_{2}$ : Puddling with rotovator $\mathrm{fb}$ spike tooth harrow; $\mathrm{L}_{3}$ : Puddling with rotomixture fb spike tooth harrow; $\mathrm{S}_{1}: 30 \times 7 \mathrm{~cm} ; \mathrm{S}_{2}: 30 \times 14 \mathrm{~cm} ; \mathrm{S}_{3}: 30 \times 21 \mathrm{~cm}$; $\mathrm{S}_{4}: 20 \times 10 \mathrm{~cm}$

harrow and intra plant spacing of $30 \times 21 \mathrm{~cm}$ treatment combination recorded significantly higher grain and straw yield (5388 and $6789 \mathrm{~kg} \mathrm{ha}^{-1}$, respectively) and it was found to be on par with puddling with rotovator $\mathrm{fb}$ levelling with spike tooth harrow with $20 \times 10 \mathrm{~cm}$ manual planting (5118 and $6441 \mathrm{~kg} \mathrm{ha}^{-1}$, respectively) and puddling with rotomixure fb levelling with spike tooth harrow with $30 \times 7 \mathrm{~cm}$ plant spacing (5071 and $6293 \mathrm{~kg} \mathrm{ha}^{-1}$, respectively).

Economics: Puddling with rotovator fb levelling with spike tooth harrow method of land preparation and planting at spacing of $30 \times 21 \mathrm{~cm}$ recorded higher gross returns (Rs. 87,773 and 92,779 $\mathrm{ha}^{-1}$, respectively). Net returns (Rs. 46,329 and 50,007 $\mathrm{ha}^{-1}$, respectively) and benefit cost ratio (2.14 and 2.20) over passing of cultivator twice fb puddling with disc puddler fb levelling with spike tooth harrow and manual planting, but were found to be on par with puddling by rotomixure $\mathrm{fb}$ levelling with spike tooth harrow and planting at a spacing of $30 \times 21 \mathrm{~cm}$ The interaction effect of land preparation and spacing between on gross and net returns was significant. Puddling with rotovator fb levelling with spike tooth harrow with planting at spacing of $30 \times 21 \mathrm{~cm}$ treatment combi- nation recorded significantly higher gross and net returns (96,316 and 54,649 $\mathrm{ha}^{-1}$, respectively) over rest of the treatment combinations.

\section{Conclusion}

Puddling with rotovator fb levelling with spike tooth harrow was found to be the best for transplanting of rice by self propelled mechanical transplanter. As this treatment recorded higher net returns (Rs. 46329) and B:C of 2.14. Among the different planting geometry, $30 \times 21 \mathrm{~cm}$ was found to be better over other planting geometry tested by visualizing higher net returns (Rs. 50007) and B:C of 2.20 .

\section{REFERENCES}

Anonymous, (2008), The Hindu Survey of Indian Agric., pp. 23-26.

Behera, B.K. (2000). Investigation on puddle soil characteristics in relation to performance of self propelled rice transplanter. Un-published Ph.D. Thesis G. B. Pant University of Ag. \& Tech., Pantnagar, UP.

Behera, B.K., Varshney, B.P. and Goel, A.K. (2009). Effect of puddling on puddled soil characteristics and performance of self-propelled transplanter in rice crop. Agricultural Engineering International. 10: 8-20 
Table 4. Gross returns, net returns and B:C of machine transplanted rice as influenced by land preparation methods and planting geometry.

\begin{tabular}{|c|c|c|c|c|c|c|c|c|c|}
\hline \multirow{2}{*}{ Treatments } & \multicolumn{3}{|c|}{ Gross returns ( $\left.\mathrm{ha}^{-1}\right)$} & \multicolumn{3}{|c|}{ Net returns $\left(\mathrm{ha}^{-1}\right)$} & \multicolumn{3}{|c|}{ Benefit cost ratio } \\
\hline & 2012 & 2013 & Pooled & 2012 & 2013 & Pooled & 2012 & 2013 & Pooled \\
\hline \multicolumn{10}{|c|}{ Main treatments $(\mathrm{L})$} \\
\hline $\mathrm{L}_{1}$ & 83900 & 77764 & 80832 & 42271 & 30153 & 36212 & 2.02 & 1.64 & 1.83 \\
\hline $\mathrm{L}_{2}$ & 91187 & 84279 & 87733 & 52590 & 40068 & 46329 & 2.36 & 1.91 & 2.14 \\
\hline $\mathrm{L}_{3}$ & 88987 & 82345 & 85666 & 50206 & 38002 & 44104 & 2.30 & 1.87 & 2.09 \\
\hline S.Em. \pm & 905 & 905 & 905 & 1229 & 1229 & 1229 & 0.04 & 0.03 & 0.03 \\
\hline C.D. $(\mathrm{P}=0.05)$ & 3552 & 3552 & 3552 & 4826 & 4826 & 4826 & 0.18 & 0.10 & 0.10 \\
\hline \multicolumn{10}{|c|}{ Sub treatments (S) } \\
\hline$\overline{\mathrm{S}_{1}}$ & 85105 & 78865 & 81984 & 45523 & 33556 & 39539 & 2.16 & 1.75 & 1.95 \\
\hline $\mathrm{S}_{2}$ & 90237 & 83535 & 86886 & 50502 & 38086 & 44294 & 2.28 & 1.85 & 2.07 \\
\hline $\mathrm{S}_{3}$ & 96521 & 89037 & 92779 & 56596 & 43418 & 50007 & 2.43 & 1.96 & 2.20 \\
\hline $\mathrm{S}_{4}$ & 80237 & 74413 & 77325 & 40801 & 29238 & 35019 & 2.05 & 1.66 & 1.86 \\
\hline S.Em. \pm & 1304 & 1304 & 1304 & 1456 & 1456 & 1456 & 0.04 & 0.06 & 0.06 \\
\hline C.D. $(\mathrm{P}=0.05)$ & 4503 & 4503 & 4503 & 5040 & 5040 & 5040 & 0.15 & 0.20 & 0.20 \\
\hline \multicolumn{10}{|c|}{ Interaction (L x S) } \\
\hline $\mathrm{L}_{1} \mathrm{~S}_{1}$ & 80417 & 74692 & 77555 & 38893 & 27173 & 33033 & 1.94 & 1.57 & 1.76 \\
\hline $\mathrm{L}_{1} \mathrm{~S}_{2}$ & 88364 & 81802 & 85083 & 49851 & 37670 & 43761 & 2.29 & 1.86 & 2.08 \\
\hline $\mathrm{L}_{1} \mathrm{~S}_{3}$ & 86533 & 80100 & 83317 & 47825 & 35825 & 41825 & 2.24 & 1.81 & 2.03 \\
\hline $\mathrm{L}_{1} \mathrm{~S}_{4}$ & 88938 & 82346 & 85642 & 47158 & 34597 & 40878 & 2.13 & 1.72 & 1.93 \\
\hline $\mathrm{L}_{2} \mathrm{~S}_{1}$ & 91463 & 84678 & 88071 & 52857 & 40460 & 46659 & 2.37 & 1.92 & 2.15 \\
\hline $\mathrm{L}_{2} \mathrm{~S}_{2}$ & 90312 & 83580 & 86946 & 51490 & 39201 & 45346 & 2.33 & 1.90 & 2.12 \\
\hline $\mathrm{L}_{2} \mathrm{~S}_{3}$ & 100410 & 92221 & 96316 & 61536 & 47761 & 54649 & 2.58 & 2.08 & 2.33 \\
\hline $\mathrm{L}_{2} \mathrm{~S}_{4}$ & 95041 & 87878 & 91460 & 53077 & 39964 & 46521 & 2.27 & 1.84 & 2.06 \\
\hline $\mathrm{L}_{3} \mathrm{~S}_{1}$ & 94112 & 87013 & 90563 & 55176 & 42531 & 48854 & 2.43 & 1.96 & 2.20 \\
\hline $\mathrm{L}_{3} \mathrm{~S}_{2}$ & 71205 & 66140 & 68673 & 29957 & 18877 & 24417 & 1.73 & 1.40 & 1.57 \\
\hline $\mathrm{L}_{3} \mathrm{~S}_{3}$ & 84512 & 78413 & 81463 & 46115 & 34382 & 40249 & 2.21 & 1.79 & 2.00 \\
\hline $\mathrm{L}_{3} \mathrm{~S}_{4}$ & 84993 & 78686 & 81840 & 46331 & 34454 & 40393 & 2.20 & 1.79 & 2.00 \\
\hline S.Em. \pm & 1620 & 1620 & 1620 & 1795 & 1795 & 1795 & 0.06 & 0.06 & 0.06 \\
\hline C.D. $(\mathrm{P}=0.05)$ & 4992 & 4992 & 4992 & NS & NS & 5530 & NS & NS & NS \\
\hline
\end{tabular}

NS - Non significant; $\mathrm{L}_{1}$ : Cultivator (twice) fb pudling with disc puddler fb spike tooth harrow (PF); $\mathrm{L}_{2}$ : Puddling with rotovator $\mathrm{fb}$ spike tooth harrow; $\mathrm{L}_{3}$ : Puddling with rotomixture fb spike tooth harrow; $\mathrm{S}_{1}: 30 \times 7 \mathrm{~cm} ; \mathrm{S}_{2}: 30 \times 14 \mathrm{~cm} ; \mathrm{S}_{3}: 30 \times 21 \mathrm{~cm}$; $\mathrm{S}_{4}: 20 \times 10 \mathrm{~cm}$

De Datta, S.K., Buresh, R.J.Samson, M.I. and Kai-rong, Wang. (1988). Nitrogen use efficiency and nitrogen balances in broad cast seeded, flooded and transplanted rice. Soil Science Society of American Journal, 52: 849-855

Duraisamy, V.M., Senthilkumar, T. and Subbulakhsmi, S. (2011). Studies on standardization of spacing and transplanting depth for a self propelled rice transplanter. Agricultural Mechanization in Asia, Africa and Latin America, 42(1): 42-44

Jackson, M.L. (1973). Soil Chemical Analysis, (Ed.). Prentice-Hall of India, Pvt. Ltd., New Delhi, pp. 121 125

Naidu, G.J., Rao, K.T., Rao, A.U. and Reddy, D.S. (2013). Age of seedling and planting pattern on grain yield, protein content, NPK uptake and post harvest nutrient status of rice under SRI. Journal of Academia and Industrial Research, 2 (6): 334-337

Olsen, S.R., Cole, C.L., Watanabe, F.S. and Deaw, D.A. (1954). Estimation of available phosphorous in soils by extraction with sodium bicarbonate. United States Departments of Agriculture circular, p.939

Rahamati, M.H. and Solakhe, V.M. (2001). Effect of tillage practices on hydraulic conductivity, cone in- dex, bulk density, infiltration rate and rice yield during rainy season in Bangkok clay soil. Agricultural Mechanization in Asia, Africa and Latin America, 32 (3): 31-34

Rasool, F. Habib, R. and Bhat, M.I. (2013). Agronomic evaluation of rice (oryza sativa L.) for plant spacing and seedlings per hill under temperate conditions. Pakistan Journal of Agriculture Science, 9(2): 169172

Razaaq, A. (1987). Preparation of medium-textured soil for rice production. Agricultural Mechanization in Asia, Africa and Latin America, 18 (1): 19-21

Sannagoudra, H.M., Dasog, G.S., Patil, P.L. and Hanamarati, N.G. (2012). Yield and nitrogen uptake by drill sown paddy as affected by different coatings of urea under two row spacings. Karnataka Journal of Agriculture Sciences, 25(4) : 535-536

Subbaiah, B.V. and Asija, G.L. (1956). Rapid procedure for determination of available nitrogen in soils. Current. Sci., 31: 196

Tripathi, S.K., Jena, H.K. and Panda, P.K. (2004). Selfpropelled rice transplanter for economizing labour. DARE/ICAR Annual Report, 23-25 